This is an electronic version of an article published in J. Coord. Chem. 2010, 63, $2779-2789$. The Journal of Coordination Chemistry is available online at:http://pdfserve.informaworld.com/702484_915549761_923032400.pdf

\title{
A Ferrocene-Based Catecholamide Ligand: the Consequences of Ligand Swivel for Directed Supramolecular Self-Assembly
}

\author{
Jeffrey S. Mugridge, Dorothea Fiedler, Kenneth N. Raymond* \\ Department of Chemistry, University of California, Berkeley, Berkeley CA 94720, and \\ Lawrence Berkeley National Laboratory, Chemical Sciences Division, Berkeley, CA 94720 \\ * Corresponding author. Email: raymond@socrates.berkeley.edu
}

A ferrocene-based biscatecholamide ligand was prepared and investigated for formation of metal-ligand supramolecular assemblies with different metals. Reaction with Ge(IV) was found to result in formation of a variety of $\mathrm{Ge}_{n} \mathrm{~L}_{\mathrm{m}}$ coordination complexes, including $\left[\mathrm{Ge}_{2} \mathrm{~L}_{3}\right]^{4-}$ and $\left[\mathrm{Ge}_{2} \mathrm{~L}_{2}(\mu-\mathrm{OMe})_{2}\right]^{2-}$. The ligand's ability to swivel about the ferrocenyl linker and adopt different conformations accounts for the formation of many different $\mathrm{Ge}_{n} \mathrm{~L}_{\mathrm{m}}$ species. This study demonstrates why conformational ligand rigidity is essential in the rational design and directed self-assembly of supramolecular complexes.

Keywords: Self-assembly; Supramolecular; Ferrocene; Conformational flexibility; Ligand design

\section{Introduction}

Recent interest in the fields of supramolecular chemistry, self-assembly and host-guest recognition has produced a large diversity of synthetic supramolecular assemblies. One common approach to the design and synthesis of such assemblies is the use of labile, metal-ligand interactions. Appropriately chosen ligand symmetries and incommensurate coordination numbers between ligand and metal can be used to direct the reversible self-assembly of complex supramolecular architectures [1-5]. This strategy has allowed the preparation of many metalligand based supramolecular structures such as rotaxanes and catenanes [6-8], helicates [9-11] and molecular squares, rings, grids and polyhedra [12-18].

We have previously reported on the design, synthesis and structural dynamics of triplestranded metallohelicates [11, 19-20] and tetrahedral host assemblies [4, 15, 21-25], each constructed from ligand scaffolds that use catecholamide chelating units and rely on ligand planarity for unique formation (Figure 1). In this article we examine the coordination chemistry of a ferrocene-based biscatecholamide ligand (L, Figure 2). While the extended conformation of $\mathrm{L}$ is similar in shape and symmetry to the naphthalene-based ligand (Figure 1, left), which readily self-assembles into a molecular tetrahedron, the ferrocene linker in L introduces one additional internal rotational freedom, a swivel, that allows formation of a variety of M-L coordination complexes.
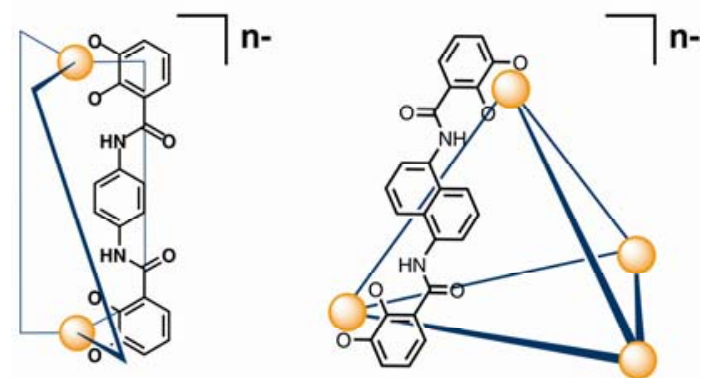

Figure 1. Schematic structures of previously prepared metallohelicate (left) and tetrahedral (right) supramolecular assemblies, only one ligand on each is shown for clarity. Note that each 
This is an electronic version of an article published in J. Coord. Chem. 2010, 63, $2779-2789$. The Journal of Coordination Chemistry is available online at:http://pdfserve.informaworld.com/702484_915549761_923032400.pdf

ligand is planar, which imposes the same chirality on bridged vertices. The offset between catecholamide chelating units provided by the naphthalene linker geometrically disfavors helicate formation, resulting in self-assembly of the tetrahedron.

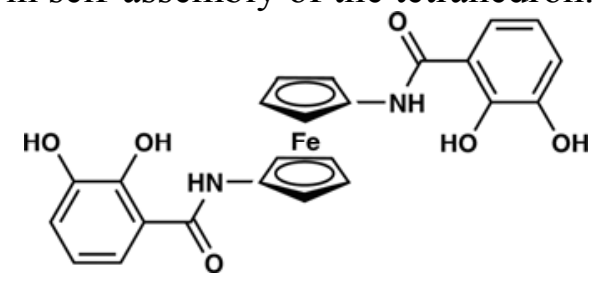

Figure 2. Ferrocenyl biscatecholamide ligand $\left(\mathrm{H}_{4} \mathrm{~L}\right)$.

Molecular mechanics modeling with the ferrocene-based ligand L (Figure 3; CAChe [26], MM3) suggests that both the $\left[\mathrm{Fe}_{2} \mathrm{~L}_{3}\right]^{6-}$ helicate and $\left[\mathrm{Fe}_{4} \mathrm{~L}_{6}\right]^{12-}$ tetrahedron are both plausible structures. The swivel motion of the ferrocenyl linker enables the ligand to adopt a geometry which can accommodate either helicate or tetrahedron. These molecular models also indicate that both the helicate and tetrahedron are more sterically crowded than the analogous structures with planar aromatic linkers shown in Figure 1 , due to the $\mathrm{Cp}\left(\mathrm{Cp}=\eta^{5}\right.$-cyclopentadienyl) hydrogen atoms which point toward the interior of each supramolecular complex. Indeed, the interior cavity of the $\left[\mathrm{Fe}_{4} \mathrm{~L}_{6}\right]^{12-}$ tetrahedron (void space calculated using Voidoo $[27,28]$ ) is only $\sim 30 \AA^{3}$, roughly the size of one water molecule.

(a)

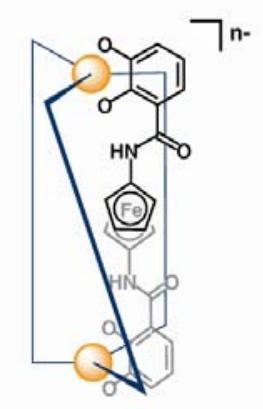

(b)

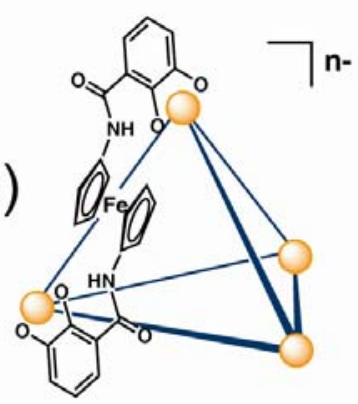

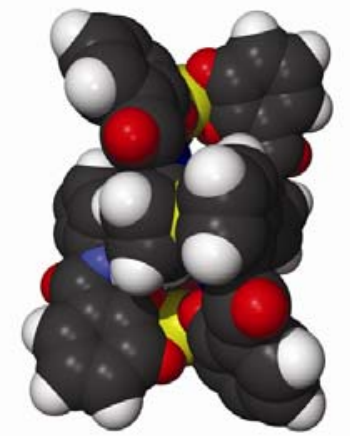

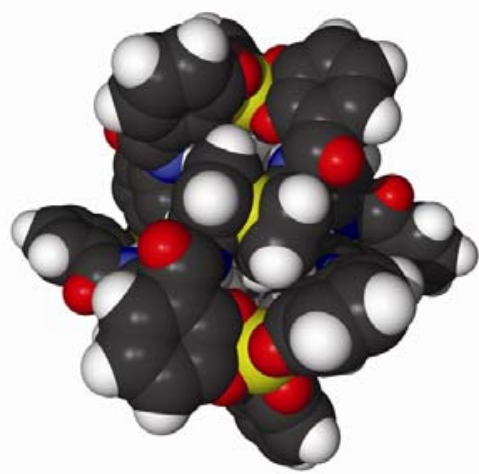

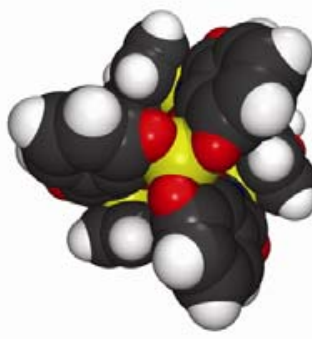

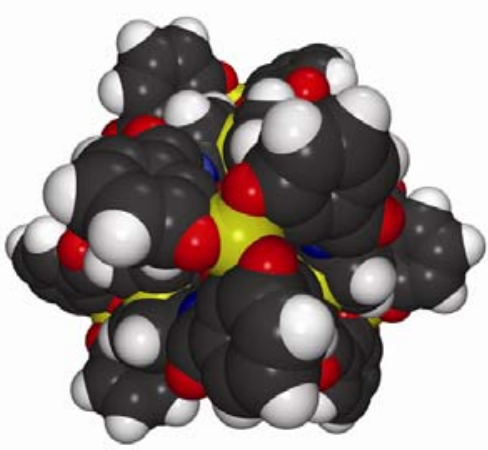

Figure 3. (a) Schematic of hypothetical $\left[\mathrm{M}_{2} \mathrm{~L}_{3}\right]^{\mathrm{n}-}$ helicate, only one ligand is shown for clarity (left); Molecular mechanics (CAChe, MM3) minimized model of $\left[\mathrm{Fe}_{2} \mathrm{~L}_{3}\right]^{6-}$ helicate (right). (b) 
This is an electronic version of an article published in J. Coord. Chem. 2010, 63, $2779-2789$. The Journal of Coordination Chemistry is available online at:http://pdfserve.informaworld.com/702484_915549761_923032400.pdf

Schematic of hypothetical $\left[\mathrm{M}_{4} \mathrm{~L}_{6}\right]^{\mathrm{n}-}$ tetrahedron, only one ligand is shown for clarity (left); Molecular mechanics (CAChe, MM3) minimized model of $\left[\mathrm{Fe}_{4} \mathrm{~L}_{6}\right]^{12-}$ tetrahedron (right).

Herein we describe the coordination chemistry of the ferrocene-based ligand L, which is found to form several different coordination complexes including a $\left[\mathrm{Ge}_{2} \mathrm{~L}_{3}\right]^{4-}$ triple-stranded metallohelicate or mesocate and an unexpected $\left[\mathrm{Ge}_{2} \mathrm{~L}_{2}(\mu-\mathrm{OMe})_{2}\right]^{2-}$ complex. The formation of these geometrically dissimilar structures and the absence of any observable tetrahedron formation illustrate how the added degree of motional freedom in L eliminates the unique assembly of a discrete supramolecular complex; the symmetry information which directs tetrahedron self-assembly in the rigid naphthalene-based ligand system is destroyed by the conformational flexibility of L. This sharply illustrates that ligand geometric rigidity and preorganization are vital for controlling the self-assembly of metal-ligand supramolecular structures.

\section{Experimental}

\subsection{General}

All reagents were obtained from commercial suppliers and used without further purification unless otherwise noted. 1,1'-diaminoferrocene was prepared following a literature procedure [29]. All NMR spectra were recorded using either Bruker AV-500 or DRX-500 MHz spectrometers at the indicated frequencies. All ${ }^{1} \mathrm{H}$ NMR chemical shifts are reported in parts per million $(\delta)$ relative to residual protic solvent resonances. Multiplicities of ${ }^{1} \mathrm{H}$ NMR resonances are reported as $\mathrm{s}=$ singlet, $\mathrm{d}=$ doublet, $\mathrm{t}=$ triplet, $\mathrm{m}=$ multiplet and $\mathrm{br}=$ broad. The ${ }^{13} \mathrm{C}\left\{{ }^{1} \mathrm{H}\right\}$ NMR spectrum of $\left[\mathrm{Ge}_{2} \mathrm{~L}_{2}\left(\mu-\mathrm{OCD}_{3}\right)_{2}\right]^{2-}$ was recorded using an HSQC experiment. As such, ${ }^{13} \mathrm{C}$ signals for quanternary carbon atoms and deuterated carbon atoms are not reported for this complex. All mass spectra were recorded at the UC Berkeley Mass Spectrometry facility. Mass spectra of all $\mathrm{Ge}_{\mathrm{n}} \mathrm{L}_{\mathrm{m}}$ complexes were acquired on a Waters QTOF API mass spectrometer.

\subsection{Ligand synthesis}

$\mathbf{F c}\left[\mathbf{N H C}(\mathbf{O}) \mathbf{c a t}(\mathbf{O B n})_{2}\right]_{2} \quad\left(\mathbf{B n}_{4} \mathrm{~L}\right) .2$ 2,3-dibenzoxybenzoic acid (1.63 g, $\left.4.86 \mathrm{mmol}\right)$ was placed in a dry Schlenk flask, cooled to $0{ }^{\circ} \mathrm{C}$ and $\mathrm{SOCl}_{2}(3 \mathrm{~mL})$ was added via syringe. Upon addition of 5 drops of DMF the suspension turned clear and was then stirred for $2 \mathrm{~h}$ at room temperature. All volatile materials were removed under reduced pressure, the pale yellow residue was washed with $3 \times 5 \mathrm{~mL}$ of dry $\mathrm{CH}_{2} \mathrm{Cl}_{2}$ and the product dried in vacuo. The acid chloride was then dissolved in $20 \mathrm{~mL}$ of $\mathrm{CH}_{2} \mathrm{Cl}_{2}, 2 \mathrm{~mL}$ of triethylamine were added and the solution was sparged with $\mathrm{N}_{2} .1,1^{\prime}$-diaminoferrocene $(500 \mathrm{mg}, 2.31 \mathrm{mmol})$ was placed in a Schlenk flask and the acid chloride solution was added via cannula. The dark orange reaction mixture was stirred for $12 \mathrm{~h}$ at room temperature. The solution was extracted with 2 × $50 \mathrm{~mL}$ of $1 \mathrm{~N} \mathrm{NaOH}, 1$ x 50 $\mathrm{mL} 1 \mathrm{~N} \mathrm{HCl}, 1 \times 50 \mathrm{~mL}$ of $\mathrm{H}_{2} \mathrm{O}$ and $2 \times 50 \mathrm{~mL}$ of brine and the orange solution was dried over $\mathrm{MgSO}_{4}$. The volume was then reduced to $15 \mathrm{~mL}$ and $100 \mathrm{~mL}$ of hexane were added. The bright orange microcrystalline precipitate was isolated by filtration and dried under reduced pressure. The product was isolated in $72 \%$ yield $(1.41 \mathrm{~g}, 1.66 \mathrm{mmol}) .{ }^{1} \mathrm{H} \mathrm{NMR}\left(500 \mathrm{MHz}, \mathrm{CD}_{2} \mathrm{Cl}_{2}\right): \delta 9.18$ (s, 2H, N-H), $7.53\left(\mathrm{dd},{ }^{3} \mathrm{~J}_{\mathrm{H}-\mathrm{H}}=8.0 \mathrm{~Hz},{ }^{4} J_{\mathrm{H}-\mathrm{H}}=1.6 \mathrm{~Hz}, 2 \mathrm{H}, \mathrm{Ar}-\mathrm{H}\right), 7.44-7.33(\mathrm{~m}, 20 \mathrm{H}, \mathrm{Ar}-\mathrm{H})$, $7.06\left(\mathrm{dd},{ }^{3} J_{\mathrm{H}-\mathrm{H}}=8.1 \mathrm{~Hz},{ }^{4} J_{\mathrm{H}-\mathrm{H}}=1.6 \mathrm{~Hz}, 2 \mathrm{H}, \mathrm{Ar}-\mathrm{H}\right), 6.96\left(\mathrm{t},{ }^{3} J_{\mathrm{H}-\mathrm{H}}=8.0 \mathrm{~Hz}, 2 \mathrm{H}, \mathrm{Ar}-\mathrm{H}\right), 5.12(\mathrm{~s}$, 
This is an electronic version of an article published in J. Coord. Chem. 2010, 63, $2779-2789$. The Journal of Coordination Chemistry is available online at:http://pdfserve.informaworld.com/702484_915549761_923032400.pdf

4H, $\left.\mathrm{CH}_{2} \mathrm{Ph}\right), 5.09$ (s, 4H, CH $\left.\mathrm{CH}_{2} \mathrm{Ph}\right), 4.34(\mathrm{~m}, 4 \mathrm{H}, \mathrm{Cp}-\mathrm{H}), 3.89(\mathrm{~m}, 4 \mathrm{H}, \mathrm{Cp}-\mathrm{H}) \mathrm{ppm} .{ }^{13} \mathrm{C}\left\{{ }^{1} \mathrm{H}\right\} \mathrm{NMR}$ $\left(500 \mathrm{MHz}, \mathrm{CD}_{2} \mathrm{Cl}_{2}\right): 162.8(\mathrm{NC}=\mathrm{O}), 151.9,146.7,137.1,136.9,129.2,129.0,129.0,128.9$, 128.6, 128.0, 127.2, 124.4, 123.3 (aromatics), $117.0(\mathrm{Cp}), 76.2\left(\mathrm{CH}_{2} \mathrm{Ph}\right), 71.5\left(\mathrm{CH}_{2} \mathrm{Ph}\right), 65.5$ (Cp), 62.7 (Cp) ppm. MS (FABLR) $m / z: 848\left(\mathrm{M}^{+}\right)$, MS (FABHR) for $\mathrm{C}_{52} \mathrm{H}_{44} \mathrm{~N}_{2} \mathrm{O}_{6} \mathrm{Fe}\left(\mathrm{M}^{+}\right)$, calcd (found) $m / z: 848.2549$ (848.2536), MS (FABHR) for $\mathrm{C}_{52} \mathrm{H}_{45} \mathrm{~N}_{2} \mathrm{O}_{6} \mathrm{Fe}\left(\mathrm{MH}^{+}\right.$), calcd (found) $m / z$ : 849.2627 (849.2578).

$\mathbf{F c}\left[\mathbf{N H C}(\mathbf{O}) \mathbf{c a t}(\mathbf{O H})_{2}\right]_{2} \quad\left(\mathbf{H}_{4} \mathbf{L}\right) . \quad \mathbf{B n}_{4} \mathbf{L}(650 \mathrm{mg}, 0.766 \mathrm{mmol})$ was dissolved in $100 \mathrm{~mL}$ THF and $150 \mathrm{mg}$ of $\mathrm{Pd} / \mathrm{C}(10 \%)$ were slowly added. The flask was purged with $\mathrm{H}_{2}$ several times. The reaction mixture was stirred at room temperature under a positive pressure of $\mathrm{H}_{2}$ for $12 \mathrm{~h}$. The solution was filtered and the solvent from the orange filtrate was removed under reduced pressure. The resulting brown residue was dissolved in $100 \mathrm{~mL} \mathrm{CH}_{2} \mathrm{Cl}_{2}$, the solution was filtered and $250 \mathrm{~mL}$ hexane was added, yielding a fluffy orange precipitate. The product was isolated by filtration and dried in vacuo. (283 mg, $0.580 \mathrm{mmol}, 76 \%$ yield). ${ }^{1} \mathrm{H}$ NMR (500 MHz, DMSO$\left.d_{6}\right): \delta 12.27(\mathrm{~s}, 2 \mathrm{H}, \mathrm{O}-\mathrm{H}), 9.74(\mathrm{~s}, 2 \mathrm{H}, \mathrm{N}-\mathrm{H}), 9.15(\mathrm{~s}, 2 \mathrm{H}, \mathrm{O}-\mathrm{H}), 7.28\left(\mathrm{~d},{ }^{3} J_{\mathrm{H}-\mathrm{H}}=7.9 \mathrm{~Hz}, 2 \mathrm{H}, \mathrm{Ar}-\right.$ $\mathrm{H}), 6.88\left(\mathrm{~d},{ }^{3} J_{\mathrm{H}-\mathrm{H}}=7.6 \mathrm{~Hz}, 2 \mathrm{H}, \mathrm{Ar}-\mathrm{H}\right), 6.61\left(\mathrm{t},{ }^{3} J_{\mathrm{H}-\mathrm{H}}=7.9 \mathrm{~Hz}, 2 \mathrm{H}, \mathrm{Ar}-\mathrm{H}\right), 4.75(\mathrm{~m}, 4 \mathrm{H}, \mathrm{Cp}-\mathrm{H})$, $4.05(\mathrm{~m}, 4 \mathrm{H}, \mathrm{Cp}-\mathrm{H}) \mathrm{ppm} .{ }^{13} \mathrm{C}\left\{{ }^{1} \mathrm{H}\right\}$ NMR (500 MHz, $\left.\mathrm{CD}_{2} \mathrm{Cl}_{2}\right): 168.2(\mathrm{NC}=\mathrm{O}), 149.0,146.1$, 118.8, 117.9, 117.6, 115.7 (aromatics), 94.9, 65.4, 62.7 (Cp) ppm. MS (FABLR) m/z: $488\left(\mathrm{M}^{+}\right.$), MS (FABHR) for $\mathrm{C}_{24} \mathrm{H}_{20} \mathrm{~N}_{2} \mathrm{O}_{6} \mathrm{Fe}$, calcd (found) $\mathrm{m} / z: 488.0671$ (488.0661).

\subsection{Ge-L complexes}

$\left[\mathbf{G e}_{2} \mathbf{L}_{\mathbf{2}}\left(\boldsymbol{\mu}-\mathbf{O C D}_{3}\right)_{2}\right]^{2-}$. $300 \mu \mathrm{L}$ of a $17.2 \mathrm{mM} \mathrm{DMF}-d_{7}$ stock solution of $\mathrm{H}_{4} \mathrm{~L}(0.005 \mathrm{mmol})$ was combined in an NMR tube with $112 \mu \mathrm{L}$ of a $46 \mathrm{mM}$ DMF- $d_{7}$ stock solution of $\mathrm{Ge}\left(\mathrm{O}^{i} \mathrm{Pr}\right)_{4}(0.005$ mmol) and diluted with an additional $100 \mu \mathrm{L}$ of DMF- $d_{7}$. The orange solution was sealed in the NMR tube under vacuum and heated to $105^{\circ} \mathrm{C}$ for 16 hours. $250 \mu \mathrm{L}$ of the resulting dark orange solution was then diluted with $300 \mu \mathrm{L} \mathrm{CD}_{3} \mathrm{OD}$. The title complex is formed quantitatively as measured by ${ }^{1} \mathrm{H}$ NMR. Excess solid sodium bicarbonate was added to the solution before MS measurements. ${ }^{1} \mathrm{H}$ NMR (500 MHz, DMF- $\left.d_{6} / \mathrm{CD}_{3} \mathrm{OD}\right): \delta 7.18\left(4 \mathrm{H}, \mathrm{d}, J_{\mathrm{H}-\mathrm{H}}=8.3 \mathrm{~Hz}, \mathrm{Ar}-\mathrm{H}\right), 6.77$ $\left(4 \mathrm{H}, \mathrm{d}, J_{\mathrm{H}-\mathrm{H}}=7.6 \mathrm{~Hz}, \mathrm{Ar}-\mathrm{H}\right), 6.52\left(4 \mathrm{H}, \mathrm{t}, J_{\mathrm{H}-\mathrm{H}}=7.8 \mathrm{~Hz}, \mathrm{Ar}-\mathrm{H}\right), 5.52(4 \mathrm{H}, \mathrm{br}, \mathrm{Cp}-\mathrm{H}), 4.37$ (4H,br, $\mathrm{Cp}-\mathrm{H}), 4.16$ (4H,br, Cp-H), 4.05 (4H,br, Cp-H). ${ }^{13} \mathrm{C}\left\{{ }^{1} \mathrm{H}\right\}\left(126 \mathrm{MHz}, \mathrm{DMF}-d_{6} / \mathrm{CD}_{3} \mathrm{OD}\right): \delta 117.7$, 116.3, 113.5 (Ar-C), 64.8, 63.8, 63.4, 59.4 (Cp-C). HRMS (ESI-QTOF): calcd (found) $\mathrm{m} / z$ : $\left[\mathrm{Ge}_{2} \mathrm{~L}_{2}\left(\mathrm{OCD}_{3}\right)_{2}{ }^{2-}+\mathrm{Na}^{+}\right]^{1-} 1209.001 \quad(1208.998), \quad\left[\mathrm{Ge}_{2} \mathrm{~L}_{2}\left(\mathrm{OCD}_{3}\right)\right]^{1-} 1151.976$ (1151.975), $\left[\mathrm{Ge}_{2} \mathrm{~L}_{2}\left(\mathrm{OCD}_{3}\right)_{2}\right]^{2-} 593.006(592.961)$.

$\left[\mathbf{G e}_{2} \mathbf{L}_{\mathbf{2}}\left(\boldsymbol{\mu}-\mathrm{OCH}_{3}\right)_{2}\right]^{2-}$. The title complex was prepared analogously to $\left[\mathrm{Ge}_{2} \mathrm{~L}_{2}\left(\mu-\mathrm{OCD}_{3}\right)_{2}\right]^{2-}$, but diluted with $\mathrm{CH}_{3} \mathrm{OH}$ rather than $\mathrm{CD}_{3} \mathrm{OD}$. The high concentration of $\mathrm{CH}_{3} \mathrm{OH}$ precluded any NMR measurements. Excess solid sodium bicarbonate was added to the solution before MS measurements. HRMS (ESI-QTOF): calcd (found) $\mathrm{m} / z$ : $\left[\mathrm{Ge}_{2} \mathrm{~L}_{2}\left(\mathrm{OCH}_{3}\right)_{2}{ }^{2-}+\mathrm{Na}^{+}\right]^{1-} 1198.944$ (1198.921), $\left[\mathrm{Ge}_{2} \mathrm{~L}_{2}\left(\mathrm{OCH}_{3}\right)\right]^{1-} 1144.936$ (1144.927), $\left[\mathrm{Ge}_{2} \mathrm{~L}_{2}\left(\mathrm{OCH}_{3}\right)_{2}\right]^{2-} 587.978$ (587.934).

\subsection{X-ray Crystallography}

Single crystals of $\left[\mathbf{G e}_{2} \mathbf{L}_{2}\left(\boldsymbol{\mu}-\mathbf{O C} \mathbf{H}_{3}\right)_{2}\right]^{2-}$ suitable for x-ray diffraction experiments were grown by diffusing diethyl ether into a solution of DMF- $d_{7} / \mathrm{CH}_{3} \mathrm{OH}$ with excess $\mathrm{NaHCO}_{3}$ present at $5{ }^{\circ} \mathrm{C}$. The yellow, plate-like crystal selected for the diffraction experiment had dimensions $0.015 \mathrm{x}$ 
This is an electronic version of an article published in J. Coord. Chem. 2010, 63, $2779-2789$. The Journal of Coordination Chemistry is available online at:http://pdfserve.informaworld.com/702484_915549761_923032400.pdf

$0.03 \times 0.08 \mathrm{~mm}$. Diffraction data were collected on a Bruker Apex II CCD area detector with $\mathrm{Cu}$ $\mathrm{K} \alpha$ radiation at $100 \mathrm{~K}$. Data were integrated using SAINT [30] and an empirical absorption correction was applied using SADABS [31] in Bruker Apex2 software. The structure was solved by direct methods (SIR92) and refined using Fourier techniques in SHELXL-97 [32]. Hydrogen atoms were placed in idealized geometries and constrained to ride on their parent atoms. Disordered DMF C, N and $\mathrm{O}$ atoms were treated isotropically. The structure was deposited in the Cambridge Crystallographic Data Center, CCDC No. 764365. Relevant Crystallographic data and structural refinement information are given in Table 1.

Table 1. Cyrstallographic data and structural refinement information for $(\mathrm{DMF})_{6} \mathrm{Na}_{2}\left[\mathrm{Ge}_{2} \mathrm{~L}_{2}(\mu-\right.$ $\left.\mathrm{OCH}_{3}\right)_{2}$.

\begin{tabular}{ll}
\hline Empirical formula & $\mathrm{C}_{68} \mathrm{H}_{80} \mathrm{Fe}_{2} \mathrm{Ge}_{2} \mathrm{~N}_{10} \mathrm{Na}_{2} \mathrm{O}_{20}$ \\
Formula weight & 1660.37 \\
Crystal system & Monoclinic \\
Space group & $\mathrm{P} 2{ }_{1} / \mathrm{c}$ \\
Unit cell dimensions $(\AA)$ & \\
$a$ & $12.1549(4)$ \\
$b$ & $19.9817(7)$ \\
$c$ & $16.2731(4)$ \\
$\alpha$ & 90.00 \\
$\beta$ & $111.265(2)$ \\
$\gamma$ & 90.00 \\
Volume $\left(\AA^{3}\right), Z$ & $3683.2(2), 2$ \\
Absorption coefficient, $\mu\left(\mathrm{mm}^{-1}\right)$ & 4.81 \\
Reflections collected/unique & $35,673 / 6605$ \\
Goodness-of-fit on $F^{2}$ & 1.057 \\
Final R indices $[I>2 \sigma(I)]$ & $\mathrm{R} 1=0.0525, \mathrm{wR} 2=0.1664$ \\
\hline
\end{tabular}

\section{Results and Discussion}

A variety of reaction conditions were screened to test for the assembly of any discrete $\mathrm{M}_{\mathrm{n}} \mathrm{L}_{\mathrm{m}}$ supramolecular complexes. Different metals $\left(\mathrm{Ga}^{3+}, \mathrm{Al}^{3+}, \mathrm{Ge}^{4+}\right)$, solvents $\left(\mathrm{CD}_{3} \mathrm{OD}, \mathrm{DMF}-d_{7}\right.$, $\mathrm{D}_{2} \mathrm{O}$ ), bases $\left(\mathrm{KOD}, \mathrm{NEt}_{3}\right)$, reaction temperatures $\left(25-135^{\circ} \mathrm{C}\right), \mathrm{M}: \mathrm{L}$ ratios $(1: 1,2: 3)$ and concentrations $([\mathrm{L}]=1-20 \mathrm{mM})$ were investigated via NMR tube-scale experiments. The only set of reaction conditions that was found to reproducibly yield one major species by ${ }^{1} \mathrm{H}$ NMR was heating $\mathrm{Ge}\left(\mathrm{O}^{i} \mathrm{Pr}\right)_{4}$ and $\mathrm{L}$ in DMF- $d_{7}$ at $105^{\circ} \mathrm{C}$ for $12-24$ hours. Under these conditions the major species formed has symmetry consistent with both the $\left[\mathrm{Ge}_{2} \mathrm{~L}_{3}\right]^{4-}$ helicate and $\left[\mathrm{Ge}_{4} \mathrm{~L}_{6}\right]^{8-}$ tetrahedron (Figure 4a). High resolution mass spectra of the DMF- $d_{7}$ solution shown in Figure 4a after dilution with either ${ }^{i} \mathrm{PrOH}$ or $\mathrm{EtOH}$, have major peaks consistent with the charged species: $\left[\mathrm{Ge}_{2} \mathrm{~L}_{2} \mathrm{ONa}\right]^{1-},\left[\mathrm{Ge}_{2} \mathrm{~L}_{2} \mathrm{O}\right]^{1-},\left[\mathrm{Ge}_{2} \mathrm{~L}_{2} \mathrm{O}\right]^{2-}$ and $[\mathrm{GeL}(\mathrm{OR})]^{1-}\left(\mathrm{R}=\mathrm{Et}\right.$ or $\left.{ }^{i} \mathrm{Pr}\right)$. It is ambiguous if these species correspond to discrete complexes in solution or are rather fragments of larger coordination complexes. Minor peaks in the mass spectra however do reveal the presence of a $\left[\mathrm{Ge}_{2} \mathrm{~L}_{3}\right]^{4-}$ complex (Figure 5). Excellent agreement between observed and predicted masses and 
This is an electronic version of an article published in J. Coord. Chem. 2010, 63, $2779-2789$. The Journal of Coordination Chemistry is available online at:http://pdfserve.informaworld.com/702484_915549761_923032400.pdf

isotope patterns for multiple charge states of this species in the mass spectra unambiguously confirm its formation. The $\left[\mathrm{Ge}_{2} \mathrm{~L}_{3}\right]$ stoichiometry suggests formation of a triple-stranded metallohelicate or mesocate. While it is possible that the major species observed by ${ }^{1} \mathrm{H} N M R$ in Figure $4 \mathrm{a}$ is the metallohelicate or mesocate, since mass spectrometry does not provide information about molecular structure or the relative amounts of species in solution, this remains uncertain.

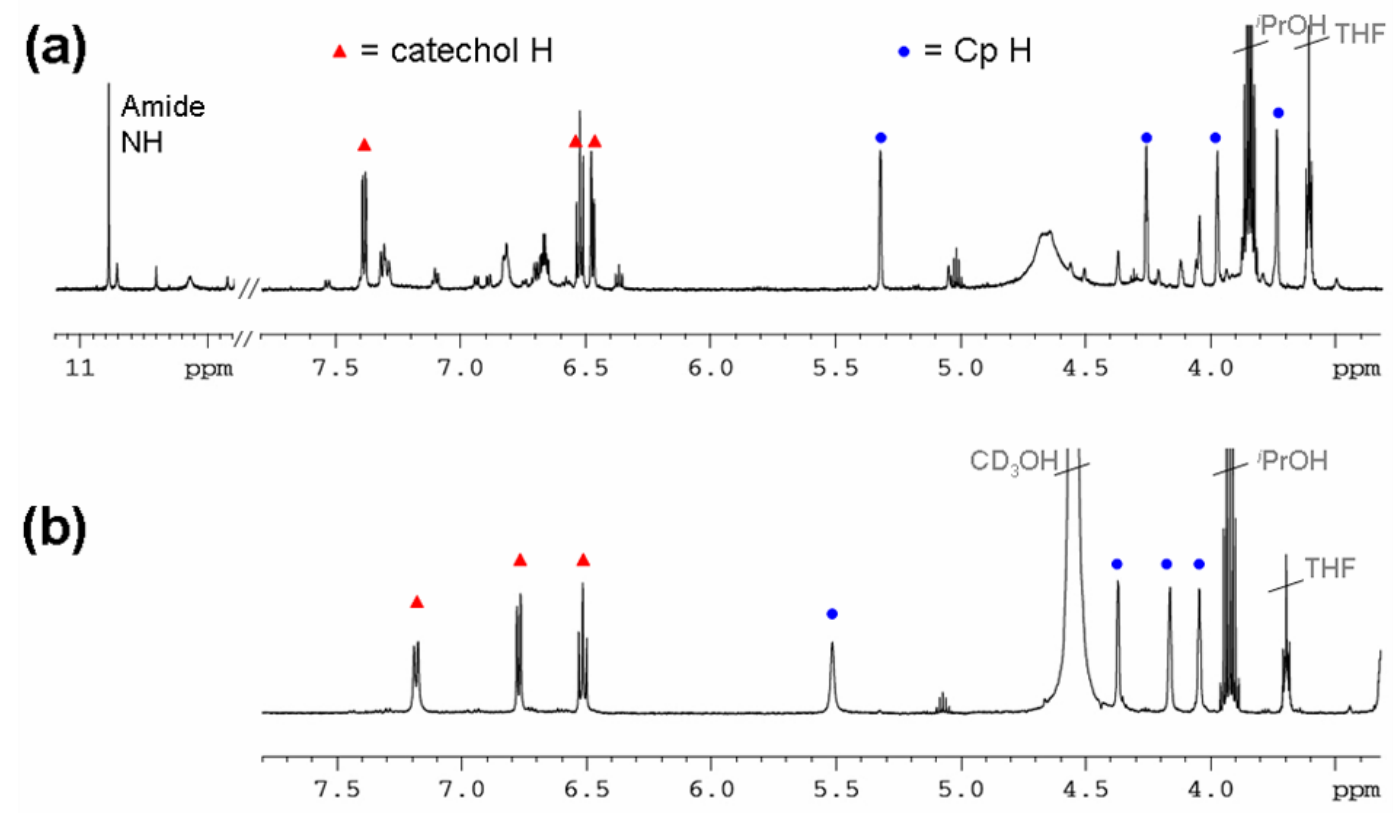

Figure 4. (a) ${ }^{1} \mathrm{H} \mathrm{NMR}$ spectrum of $\mathrm{Ge}\left(\mathrm{O}^{i} \mathrm{Pr}\right)_{4}+\mathrm{L}$ in $\mathrm{DMF}-d_{7}$ after heating at $105{ }^{\circ} \mathrm{C}$ for $16 \mathrm{~h}$. The number of catechol and $\mathrm{Cp}$ proton resonances is consistent with both helicate and tetrahedron formation. (b) ${ }^{1} \mathrm{H}$ NMR spectrum of $250 \mu \mathrm{L}$ of the DMF- $d_{7}$ solution shown in (a) after dilution with $300 \mu \mathrm{L} \mathrm{CD} 3 \mathrm{OD}$. Addition of methanol results in quantitative formation of the complex: $\left[\mathrm{Ge}_{2} \mathrm{~L}_{2}(\mu-\mathrm{OMe})_{2}\right]^{2-}$.

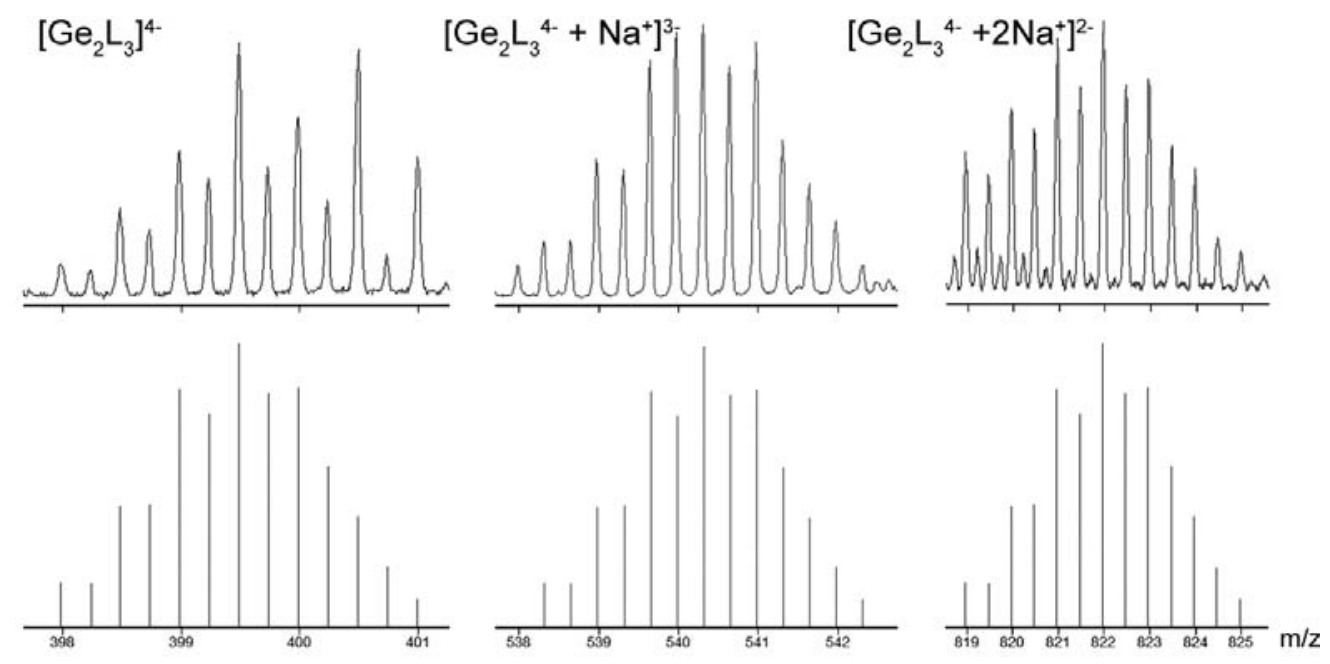


This is an electronic version of an article published in J. Coord. Chem. 2010, 63, $2779-2789$. The Journal of Coordination Chemistry is available online at:http://pdfserve.informaworld.com/702484_915549761_923032400.pdf

Figure 5. Sections of a high resolution mass spectrum (top) and simulated isotope patterns (bottom) showing the 4-, 3- and 2- charge states of the $\left[\mathrm{Ge}_{2} \mathrm{~L}_{3}\right]^{4-}$ metallohelicate/mesocate. This spectrum was acquired from the DMF- $d_{7}$ solution shown in Figure $4 \mathrm{a}$ after addition of $\mathrm{NaHCO}_{3}$ and dilution with ethanol. Relative intensities of each section of the spectrum are not to scale. Species at $\mathrm{m} / \mathrm{z} \sim 818$ and $\sim 401$ overlap with the 2- and 4- charge states of the complex, respectively, causing some deviation from the expected intensities of the isotope pattern.

Surprisingly, when the DMF- $d_{7}$ solution shown in Figure $4 \mathrm{a}$ is diluted with $\mathrm{CD}_{3} \mathrm{OD}$, a new complex, with the same ligand symmetry as the major species in Figure 4a, is rapidly and quantitatively formed (Figure $4 \mathrm{~b}$ ). Mass spectrometry experiments reveal that the major species present correspond to the charged fragments: $\left[\mathrm{Ge}_{2} \mathrm{~L}_{2}(\mathrm{OMe})_{2} \mathrm{Na}\right]^{1-}$ and $\left[\mathrm{Ge}_{2} \mathrm{~L}_{2}(\mathrm{OMe})_{2}\right]^{2-}$; either the $\left[\mathrm{Ge}_{2} \mathrm{~L}_{2}\left(\mathrm{OCH}_{3}\right)_{2}\right]^{2-}$ or $\left[\mathrm{Ge}_{2} \mathrm{~L}_{2}\left(\mathrm{OCD}_{3}\right)_{2}\right]^{2-}$ isotopomer is formed depending on whether the DMF- $d_{7}$ solution is diluted with $\mathrm{CH}_{3} \mathrm{OH}$ or $\mathrm{CD}_{3} \mathrm{OD}$. Single crystals of this complex suitable for $\mathrm{x}$-ray diffraction experiments were grown by diffusing diethyl ether into the reaction solution of $\mathrm{DMF}-d_{7}$ diluted with $\mathrm{MeOH}$. The diffraction experiment reveals that the complex is correctly formulated as $\left.\left[\mathrm{Ge}_{2} \mathrm{~L}_{2}(\mu-\mathrm{OMe})_{2}\right)\right]^{2-}$, where each $\mathrm{Ge}$ atom is chelated by one ferrocenyl ligand and the methoxide groups bridge the two octahedrally coordinated Ge atoms (Figure 6, Table 2). The solid-state molecular structure has local $C_{2 \mathrm{~h}}$ symmetry, with the $C_{2}$ axis passing through both Ge atoms. This symmetry is consistent with the ${ }^{1} \mathrm{H}$ NMR spectrum shown in Figure $4 \mathrm{~b}$.
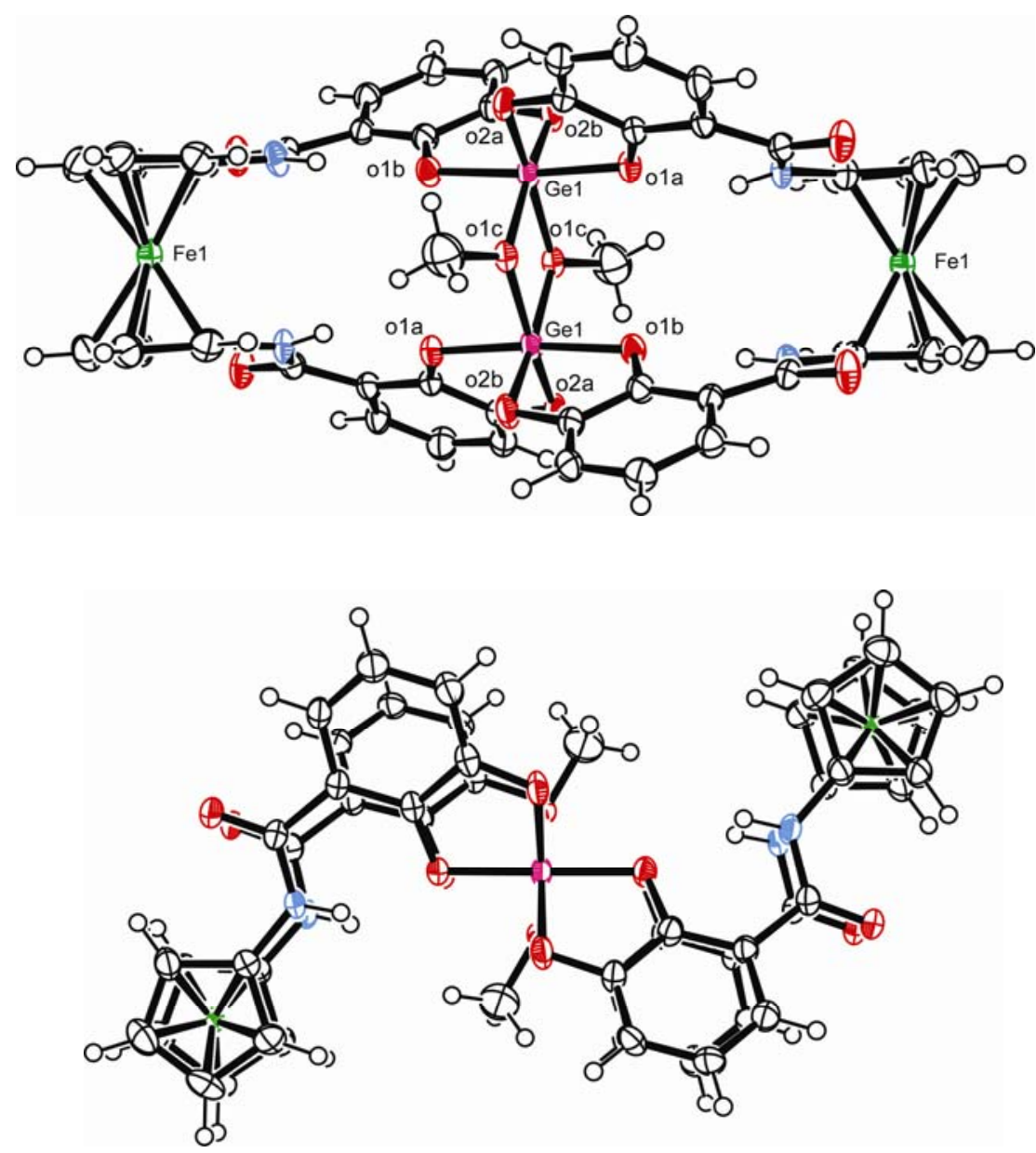
This is an electronic version of an article published in J. Coord. Chem. 2010, 63, $2779-2789$. The Journal of Coordination Chemistry is available online

at:http://pdfserve.informaworld.com/702484_915549761_923032400.pdf

Figure 6. Solid-state structure of $\left[\mathrm{Ge}_{2} \mathrm{~L}_{2}(\mu-\mathrm{OMe})_{2}\right]^{2-}$ as viewed down the local mirror plane (top) and two-fold rotation axis (bottom). Solvent (DMF) and counterions $\left(\mathrm{Na}^{+}\right)$are omitted for clarity. 
This is an electronic version of an article published in J. Coord. Chem. 2010, 63, $2779-2789$. The Journal of Coordination Chemistry is available online at:http://pdfserve.informaworld.com/702484_915549761_923032400.pdf

Table 2. Ge-O bond lengths $(\AA)$ and angles $\left(^{\circ}\right)$ for $\left[\mathrm{Ge}_{2} \mathrm{~L}_{2}(\mu-\mathrm{OMe})_{2}\right]^{2-}$. O $1 \mathrm{c}^{\prime}$ is the symmetrygenerated bridging oxygen atom.

\begin{tabular}{ll}
\hline Ge1-O1a & $1.8753(28)$ \\
Ge1-O2a & $1.8565(30)$ \\
Ge1-O1b & $1.8724(28)$ \\
Ge1-O2b & $1.8574(29)$ \\
Ge1-O1c & $1.9265(27)$ \\
Ge1-O1c' & $1.9304(29)$ \\
& \\
O1a-Ge1-O2a & $86.60(12)$ \\
O1a-Ge1-O1b & $174.67(13)$ \\
O1a-Ge1-O2b & $89.71(12)$ \\
O1a-Ge1-O1c & $92.98(12)$ \\
O1a-Ge1-O1c' & $89.73(12)$ \\
O2a-Ge1-O1b & $89.85(12)$ \\
O2a-Ge1-O2b & $103.70(14)$ \\
O2a-Ge1-O1c & $90.19(13)$ \\
O2a-Ge1-O1c' & $164.07(12)$ \\
O1b-Ge1-O2b & $87.27(12)$ \\
O1b-Ge1-O1c & $91.00(12)$ \\
O1b-Ge1-O1c' & $94.74(12)$ \\
O2b-Ge1-O1c & $165.99(13)$ \\
O2b-Ge1-O1c' & $91.77(13)$ \\
O1c-Ge1-O1c' & $74.51(12)$ \\
\hline
\end{tabular}

Based on the mass spectrometry results discussed above, neither the analogous $\left[\mathrm{Ge}_{2} \mathrm{~L}_{2}(\mathrm{OEt})_{2}\right]^{2-}$ nor $\left[\mathrm{Ge}_{2} \mathrm{~L}_{2}\left(\mathrm{O}^{i} \mathrm{Pr}\right)_{2}\right]^{2-}$ complexes are formed upon dilution of the DMF- $d_{7}$ reaction solution with EtOH or ${ }^{i} \mathrm{PrOH}$, respectively. To investigate whether or not the OEt and $\mathrm{O}^{i} \mathrm{Pr}$ fragments may be too large to serve as bridging ligands, molecular mechanics minimized (MacroModel, OPLS 2005) models of the $\left[\mathrm{Ge}_{2} \mathrm{~L}_{2}(\mathrm{OMe})_{2}\right]^{2-},\left[\mathrm{Ge}_{2} \mathrm{~L}_{2}(\mathrm{OEt})_{2}\right]^{2-}$ and $\left[\mathrm{Ge}_{2} \mathrm{~L}_{2}\left(\mathrm{O}^{i} \mathrm{Pr}\right)_{2}\right]^{2-}$ complexes were constructed. Comparison of the energy-minimized structures reveals that small distortions in ferrocenyl ligand geometry are required to accommodate the larger bridging ligands $\mathrm{OEt}$ and $\mathrm{O}^{i} \mathrm{Pr}$ (Figure 7). Specifically, the interplanar angle between the two catechol aromatic rings of each ferrocenyl ligand increases by $6^{\circ}$ for the minimized $\left[\mathrm{Ge}_{2} \mathrm{~L}_{2}(\mathrm{OEt})_{2}\right]^{2-}$ structure and $9^{\circ}$ for the minimized $\left[\mathrm{Ge}_{2} \mathrm{~L}_{2}\left(\mathrm{O}^{i} \mathrm{Pr}\right)_{2}\right]^{2-}$ structure, over that of the minimized $\left[\mathrm{Ge}_{2} \mathrm{~L}_{2}(\mathrm{OMe})_{2}\right]^{2-}$ structure. While these are only minor deformations in the ligand geometry, they are apparently sufficient to hinder formation of the $(\mu-\mathrm{OEt})$ and $\left(\mu-\mathrm{O}^{i} \mathrm{Pr}\right)$ complexes. 
This is an electronic version of an article published in J. Coord. Chem. 2010, 63, $2779-2789$. The Journal of Coordination Chemistry is available online at:http://pdfserve informaw/nrld r.nm/7n2484 $915549761 \quad 92.30 .3240 \cap \mathrm{ndf}$

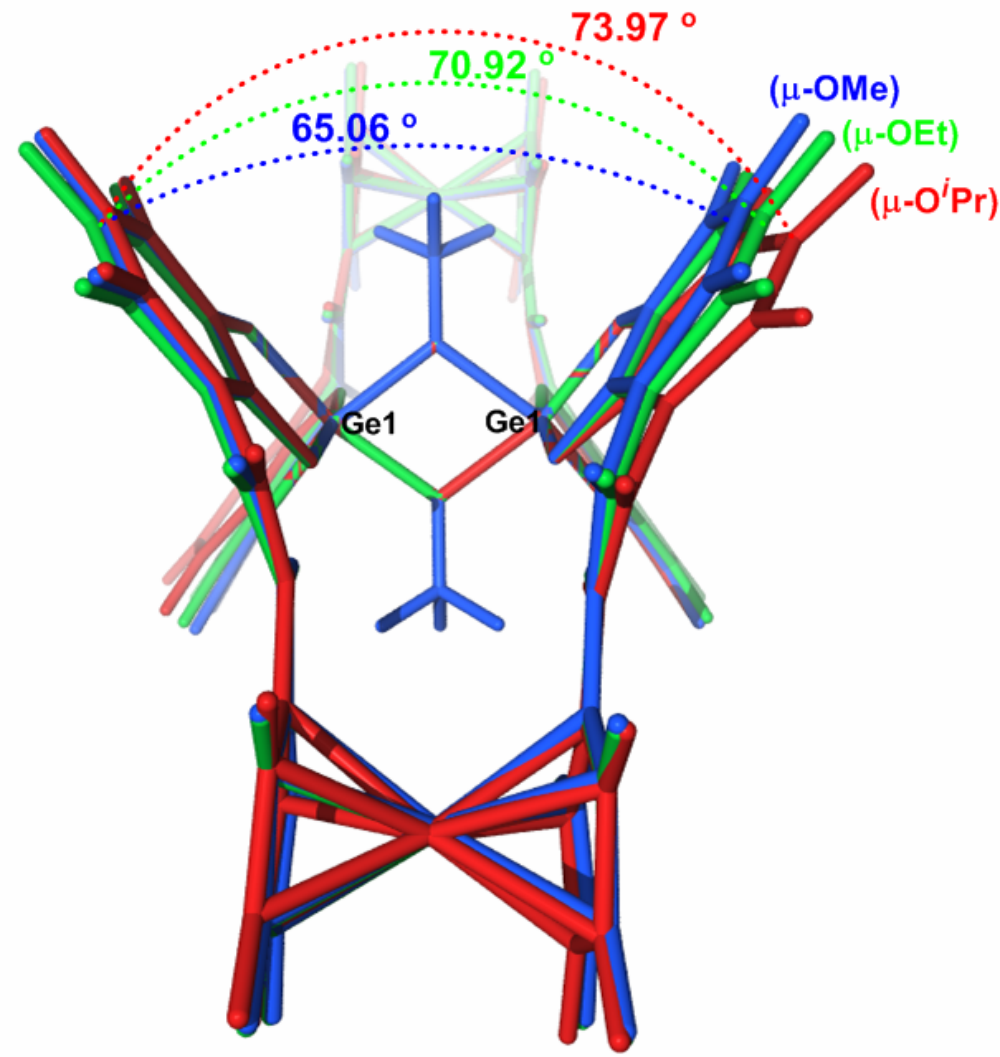

Figure 7. Overlay of mechanics minimized (OPLS 2005) $\left[\mathrm{Ge}_{2} \mathrm{~L}_{2}(\mathrm{OMe})_{2}\right]^{2-}$ (blue), $\left[\mathrm{Ge}_{2} \mathrm{~L}_{2}(\mathrm{OEt})_{2}\right]^{2-}$ (green) and $\left[\mathrm{Ge}_{2} \mathrm{~L}_{2}\left(\mathrm{O}^{i} \mathrm{Pr}\right)_{2}\right]^{2-}$ (red) structures showing distortions in the ligand geometry required to accommodate different bridging alkoxide ligands. The catechol-catechol interplanar angles are shown for each structure and colored coded accordingly. Only the $(\mu-$ $\mathrm{OMe}$ ) bridging ligands are shown for clarity.

\section{Conclusions}

A ferrocene-based biscatecholamide ligand was prepared from 1,1'-diaminoferrocene. Molecular modeling studies suggest that the internal rotational freedom introduced by the ferrocene moiety allows the ligand to adopt geometries that could accommodate formation of several supramolecular complexes such as the $\mathrm{M}_{2} \mathrm{~L}_{3}$ metallohelicate or $\mathrm{M}_{4} \mathrm{~L}_{6}$ tetrahedron. Experimentally, the coordination chemistry of the ferrocenyl ligand is complicated. When heated in the presence of $\mathrm{Ge}(\mathrm{IV})$, mass spectrometry experiments reveal the presence of the $\left[\mathrm{Ge}_{2} \mathrm{~L}_{3}\right]^{4-}$ metallohelicate or mesocate in small amounts as well as several other $\left[\mathrm{Ge}_{\mathrm{x}} \mathrm{L}_{\mathrm{y}}\right]^{\mathrm{n}-}$ coordination isomers. Addition of methanol to the DMF reaction solution results in quantitative formation of the complex $\left[\mathrm{Ge}_{2} \mathrm{~L}_{2}(\mu-\mathrm{OMe})_{2}\right]^{2-}$ as characterized by NMR spectroscopy, mass spectrometry and $\mathrm{x}$-ray crystallographic experiments.

The diversity of coordination complexes formed by the ferrocene-based ligand (L) in this study demonstrates why ligand conformational rigidity is a key factor in the rational design of supramolecular architectures. Although L can adopt a shape similar to the naphthalene-based catecholamide ligand, which readily self-assembles into a molecular tetrahedron, rotation about the ferrocenyl rings allows many other ligand conformations. The result is that $\mathrm{L}$ can form many different low-energy $\mathrm{M}_{n} \mathrm{~L}_{\mathrm{m}}$ complexes with different $\mathrm{M}: \mathrm{L}$ ratios and different coordination 
This is an electronic version of an article published in J. Coord. Chem. 2010, 63, $2779-2789$. The Journal of Coordination Chemistry is available online at:http://pdfserve.informaworld.com/702484_915549761_923032400.pdf

geometries. This behavior stands in contrast to the naphthalene-based catecholamide ligand, whose rigid, planar structure requires formation of the molecular tetrahedron to complete metalligand coordination.

\section{Supplementary materials}

Crystallographic data (CIF file) for the structure reported in this article have been deposited in the Cambridge Crystallographic Data Center, CCDC No. 764365. Copies of the data can be obtained free of charge on application to CCDC, 12 Union Road, Cambridge CB2 1EZ, UK, or online from www.ccdc.cam.ac.uk. Mass spectra of $\left[\mathrm{Ge}_{2} \mathrm{~L}_{2}\left(\mu-\mathrm{OCH}_{3}\right)_{2}\right]^{2-}$ and $\left[\mathrm{Ge}_{2} \mathrm{~L}_{2}\left(\mu-\mathrm{OCD}_{3}\right)_{2}\right]^{2-}$ as well as the ${ }^{1} \mathrm{H}_{-}{ }^{13} \mathrm{C}$ HSQC NMR spectrum for $\left[\mathrm{Ge}_{2} \mathrm{~L}_{2}\left(\mu-\mathrm{OCD}_{3}\right)_{2}\right]^{2-}$ are available as a .pdf file.

\section{Acknowledgments}

This work has been supported by the Director, Office of Science, Office of Basic Energy Sciences, and the Division of Chemical Sciences, Geosciences, and Biosciences of the U.S. Department of Energy at LBNL under Contract No. DE-AC02-05CH11231 and an NSF predoctoral fellowship to J.S.M. We thank Dr. Ulla Andersen for assistance with mass spectrometry experiments, Dr. Antonio DiPasquale for assistance with x-ray crystallographic experiments and structural refinement and Dr. Alexandr Shafir for samples of 1,1'diaminoferrocene.

\section{References}

[1] B. H. Northrop, Y. R. Zheng, K. W. Chi, P. J. Stang. Acc. Chem. Res., 42, 1544 (2009).

[2] R. W. Saalfrank, H. Maid, A. Scheurer. Angew. Chem. Int. Ed., 47, 2 (2008).

[3] M. Fujita, M. Tominaga, A. Hori, B. Therrien. Acc. Chem. Res., 38, 369 (2005).

[4] D. L. Caulder, K. N. Raymond. Acc. Chem. Res., 32, 975 (1999).

[5] J. M. Lehn. Supramolecular Chemistry: Concepts and Perspectives, Wiley-VCH, Weinheim, Germany (1995).

[6] S. J. Cantrill, K. S. Chichak, A. J. Peters, J. F. Stoddart. Acc. Chem. Res., 38, 1 (2005).

[7] T. J. Hubin, D. H. Busch. Coord. Chem. Rev., 200, 5 (2000).

[8] J. P. Sauvage, C. Dietrich-Buchecker. Molecular Catenanes, Rotaxanes and Knots, WileyVCH, Weinheim, Germany (1999).

[9] M. Albrecht. Top. Curr. Chem., 248, 105 (2004).

[10] M. Elhabiri, J. C. G. Bunzli, A. M. Albrecht-Gary. Eur. J. Inorg. Chem., 1, 51 (2004).

[11] D. L. Caulder, K. N. Raymond. Angew. Chem. Int. Ed. Engl., 36, 1439 (1997).

[12] J. K. Klosterman, Y. Yamauchi, M. Fujita. Chem. Soc. Rev., 38, 1714 (2009).

[13] B. H. Northrop, H. B. Yang, P. J. Stang. Chem. Commun., 45, 5896 (2008).

[14] M. Ruben, J. Rojo, F. J. Romero-Salguero, L. H. Uppadine, J. M. Lehn. Angew. Chem. Int. Ed. Engl., 43, 3644 (2004).

[15] D. L. Caulder, C. Bruckner, R. E. Powers, S. Konig, T. N. Parac, J. A. Leary, K. N. Raymond. J. Am. Chem. Soc., 123, 8923 (2001).

[16] S. Leininger, B. Olenyuk, P. J. Stang. Chem. Rev., 100, 853 (2000).

[17] R. V. Slone, K. D. Benkstein, S. Belanger, J. T. Hupp, I. A. Guzei, A. L. Rheingold. Coord. Chem. Rev., 171, 221 (1998). 
This is an electronic version of an article published in J. Coord. Chem. 2010, 63, $2779-2789$. The Journal of Coordination Chemistry is available online at:http://pdfserve.informaworld.com/702484_915549761_923032400.pdf

[18] B. Hasenknopf, J. M. Lehn, B. O. Kneisel, G. Baum, D. Fenske. Angew. Chem. Int. Ed. Engl., 35, 1838 (1996).

[19] M. Meyer, B. Kersting, R. E. Powers, K. N. Raymond. Inorg. Chem., 36, 5179 (1997).

[20] B. Kersting, M. Meyer, R. E. Powers, K. N. Raymond. J. Am. Chem. Soc., 118, 7221 (1996).

[21] M. D. Pluth, D. W. Johnson, G. Szigethy, A. V. Davis, S. J. Teat, A. G. Oliver, R. G. Bergman, K. N. Raymond. Inorg. Chem., 48, 111 (2009).

[22] S. M. Biros, R. M. Yeh, K. N. Raymond. Angew. Chem. Int. Ed. Engl., 47, 6062 (2008).

[23] R. M. Yeh, J. Xu, G. Seeber, K. N. Raymond. Inorg. Chem., 44, 6228 (2005).

[24] D. W. Johnson, K. N. Raymond. Inorg. Chem., 40, 5157 (2001).

[25] D. L. Caulder, R. E. Powers, T. N. Parac, K. N. Raymond. Angew. Chem. Int. Ed. Engl., 37, 1840 (1998).

[26] CAChe Workstation Pro, ver. 5.04; Fujitsu Ltd. (2002).

[27] G. J. Kleywegt, T. A. Jones. Acta. Crystallogr., D50, 178 (1994).

[28] G. J. Kleywegt, J. Y. Zou, M. Kjeldgaard, T. A. Jones. International Tables for Crystallography, International Union of Crystallography, Kluwer Academic, Dordrect, The Netherlands, F, 353 (2001).

[29] A. Shafir, M. P. Power, G. D. Whitener, J. Arnold. Organometallics, 19, 3978 (2000).

[30] SAINT: SAX Area-Detector Integration Program, version 7.07B, Siemens Industrial Automation, Inc., Madison, WI (1999).

[31] G. M. Sheldrick. SADABS: Siemens Area Detector Absorption Correction Program, version 2.10, University of Göttingen, Germany (2005).

[32] G. M. Sheldrick. SHELX97: Programs for Crystal Structure Analysis, release 97-2, Institut für Anorganische Chemie der Universität: Göttingen, Germany (1998). 